\title{
Comprehensive Strategy to Inculcate Professional Skills among First- Year Students: A Collaborative Learning Approach
}

\author{
Poornesh M. ${ }^{1}$, Shreeranga Bhat ${ }^{2 *}$, Rio D'Souza ${ }^{3}$, E.S.M. Suresh ${ }^{4}$, Vinayambika S. Bhat ${ }^{5}$ \\ ${ }^{1}$ Department of Mechanical Engineering, St Joseph Engineering College, Mangaluru, Karnataka, India \\ ${ }^{2}$ Department of Mechanical Engineering, St Joseph Engineering College, Mangaluru, Karnataka, India \\ ${ }^{3}$ Department of Computer Science and Engineering, St Joseph Engineering College, Mangaluru, Karnataka, India \\ ${ }^{4}$ Department of Civil and Environmental Engineering, National Institute of Technical Teachers Training and Research, \\ Chennai, Tamilnadu, India \\ ${ }^{5}$ Department of Electronics and Communication Engineering, Mangalore Institute of Technology and Engineering, \\ Moodabidri, Karnataka, India \\ ${ }^{1}$ poorneshm@sjec.ac.in \\ $2^{*}$ shreerangab@sjec.ac.in \\ ${ }^{3}$ riod@sjec.ac.in \\ 4esmsuresh@gmail.com \\ ${ }^{5}$ vinayambika09@gmail.com
}

\begin{abstract}
Inculcating teamwork, communication skills, and lifelong learning are essential metrics of Outcome Based Engineering (OBE). Ensuring these in early professional courses will enhance the ability of the students to adopt the OBE effectively in the forthcoming semesters. Effective planning and deployment of pedagogy of engagement will aid the students and faculty members to attain the desired outcomes with effective utilization of resources. This article unearths the challenges and documents the lessons learned in deploying collaborative learning in the First Year (FY) engineering education. It establishes a comprehensive assessment methodology from OBE perspective. Further, it addresses professional skills such as teamwork, communication skills, and lifelong learning in a structured manner. The Action Research methodology is adopted by taking into account the OBE approach enshrined in the Programme Outcomes (POs) as suggested by the Indian statutory bodies. The collaborative learning approach of 'Student, Teams, Achievement, Division' (STAD) is utilized by establishing a heterogeneous group. The Define-Measure-AnalyzeImprove-Control (DMAIC) approach is used for project deployment and sustainment. Statistical analysis is used to interpret the results effectively. The study shows that the desired outcomes are achieved with a minimum duration of the teaching-learning process. Moreover, statistical analysis shows that even weaker students can reach the set attainment target due to heterogeneous group formation and collaborative learning. Eventually, the structured approach assists in developing a framework for the effective
\end{abstract}

\section{Shreeranga Bhat}

Department of Mechanical Engineering, St Joseph

Engineering College, Mangaluru, Karnataka, India shreerangab@sjec.ac.in

deployment of collaborative learning by establishing robust assessment tools to address the POs related to professional skills. The study shows that collaborative learning can be effectively deployed in FY engineering education with specific reference to POs related to professional skills within the optimal duration, provided a structured approach is embraced. It is also observed that heterogeneous group formation assists slow learners to elevate themselves to progressive learners due to teamwork and the influence of wiser students.

Keywords: Professional Skills, Collaborative Learning, Outcome Based Education, First Year Engineering Education.

\section{Introduction}

Technical Education everywhere in the world is picking up significance daily due to the quick headways in Science and Technology, which leads to the developments of different disciplines through continuous and ceaseless research. To achieve the social and economic goals of any nation, Engineering and Technical education have become a prerequisite, thereby maintaining the complex structure of the entire modern society. Engineering education should not be just about taking a degree after four years. Instead, it should be about training the students in various facets of life such as team player, being a leader, entrepreneur, ability to conduct oneself in critical situations, problemsolving skills (Buke et al., 2015). It has also been mentioned in "Washington Accord", accreditation bodies like NBA, NAAC and ABET that these aspects of should be given equal importance along with curriculum and pedagogy (Mohanty and Dash, 2016). Basic tenets of Outcome Based Engineering (OBE) is to inculcate critical thinking, and thus to bridge the gap between the facets and technical education provided in the colleges (Bhat et al., 2020a).

\section{A. Outcome Based Education (OBE)}

The OBE deployment in Engineering Education is made obligatory for all the Engineering programme to attain accreditation as per the Washington Accord (Bhat et al., 2020a). The concept of OBE developed by sociologist William Spady focusses on the assessment and evaluation of the best practices so that the attainment of learning 
outcomes can be allied to the educational objectives (Froyd et al., 2012). The knowledge, skills, and attitude are the basic tenets of the OBE system. Thus students are expected to exhibit the same at the end of the topic/ course/ program (Jadhava et al., 2019). It deals with determining what the students can do and then designing the curriculum, delivering the content and then assessing them, thus making sure that the learning has happened. In any case, these require more exertion for the academic community to include not only technical skills but also evaluate soft skills and professional skills in their engineering curriculum (Bhat et al., 2020b).

\section{B. Collaborative Learning}

The ever-increasing intricacy in the current professional environment demands that their employees can collaborate with their subordinates in resolving crucial issues. In a bid to improve the skills of students, it is necessary for faculty in Engineering colleges to revise their course plan in such a way as to include collaborative learning activities along with the prescribed curriculum (Stover and Holland, 2018). Collaborative learning can be defined as an "intellectual endeavour in which individuals collaborate with others to become knowledgeable on some particular subject matter" (Koehn, 2001). The primary objective of Collaborative Learning is to create an environment in which the students come together co-develop knowledge. Doing this enables the betterment of communication skills, teamwork, social skills, and sharpen the conflict resolution capabilities in students (Bhat et al., 2020a). There are several forms of Collaborative Learning methods like Student-TeamsAchievement Divisions (STAD), Teams-GamesTournament (TGT), Jigsaw, Cooperative-IntegratedReading-and-Composition (CIRC), Learning-Together (LT), Team-Assisted Individualisation (TAI), AcademicControversy (AC), Group-Investigation (GI). (Micheal, 2012). STAD is considered as one of the easiest and most widely researched forms under collaborative learning methods as it is a powerful instrument which helps in significantly improving and hasten the performance of the student. Under this strategy, a small group of 4-5 students having a diverse level of learning ability are placed together to accomplish the given task (Bhat et al., 2020b). In the first place, the teacher describes the concepts/ lesson to the students who then get together in accordance with their teams to make sure that all the members have clearly understood the topics explained. Ultimately, the students are tested separately with the help of a definite assessment tool (Bhat et al., 2020b). Therefore, the present study deals with the implementation of this approach to meet the standards set by OBE for teaching-learning practice.

\section{Professional Skills}

The key to the student-centric learning is in the developing the professional skills of the students which they obtain throughout their training in the university thereby exhibiting it at some point of their professional career (Llorens et al., 2016). These skills go past their academic knowledge and refer to the development in their workplace through which value can be added to their existence in the industry. It was found that for the promotion of professional skills and attitudes among the graduates structured voluntary activities need to be conducted since they provide a unique blend of intrinsic motivation and serious attention which are lacking in the conventional classroom teaching (Binu et al., 2020). In that capacity, the universities should design their curriculum in such a way that the graduates attain both basic knowledge as well as professional skills that are needed by the sector. Nevertheless, the present Engineering Education scheme is lagging in providing the skills needed by the students to meet the demands required in the job market due to which the students even are well equipped in technical skills lack professional skills, which will not allow them to design innovative products/ services, and solutions (Kojmane and Aboutajeddine, 2016).

Thus, the objective of the present work is to study the challenges and record the experiences acquired in adopting collaborative learning in FY Engineering Education and to establish comprehensive assessment methodology from OBE perspective. Additionally, it addresses information regarding including professional skills such as teamwork, communication skills, and lifelong learning in a structured manner. This motivated the researchers to frame the following Research Questions (RQs):

RQ1: What is the applicability of the STAD model in the OBE deployment?

RQ2: What are the different strategies that can be used for the effective implementation of STAD model for Collaborative Learning in Engineering Education?

RQ3: What are the various outcomes that have been obtained because of the enactment of the new techniques in Engineering Education?

\section{Literature Review}

A new ubiquitous trend is seen in Engineering Education through the incorporation of Collaborative Learning. This term is considered to be a general metaphor for certain practices and techniques which involve critical thinking, and comprehensive social development of students. Kagan (Kagan, 1994) considers collaborative learning as teaching set up, which involves a faction of students divided into a small and diverse group who work together to accomplish a common goal. It has been proposed that the Collaborative Learning is made up of five elements, namely:

- Positive Interdependence

- Individual Accountability

- Promotive Interaction

- Use of Interpersonal Skills

- Monitoring of Progress (Göl Ö and Nafalski, 2007)

As an alternative to conventional classroom teaching style, Collaborative Learning, exhibit the following advantages:

- It enhances the ability of the student to comprehend the topic taught

- It helps in promoting interactive learning in students through critical thinking and problem-solving abilities 
- It improves the team working skills of the students by making them work and communicate in small groups which is a crucial trait needed in the real world

It helps in boosting the confidence of a student in his/her abilities (Bhat et al., 2020b).

It is ascertained that working efficiently with people incredibly complicated process. The process of collaborating with others to work towards a common goal is complicated since they are social skills. Thus, learning these skills requires guided practice and quality feedback. To have the ability to work as a team is an essential element in collaborative learning thus becomes a vital personal and professional skill for any graduate (Bhat et al., 2020b and 2020c).

In the present work-life conditions, wherein the contest to be better than other is growing by the day, one cannot survive only with a college degree. To be successful in a very competitive business world requires, one should be highly skilled under specific professional skills. Professional skills are those abilities that are frequently left out or not taught as an integral part of the curriculum (Kulturel-Konak et al., 2015). They are some of the common skills that nearly every company wishes his/her employee would possess. Skills like conflict resolution, leadership, project management and mentoring are some of the value-added skills vital to any professional development. With the view of incorporating technical knowledge with professional skills in the prescribed curriculum of the university, the style of teaching-learning ought to move from conventional teacher-centric technique to more of student-centric approach through the various project and problem-based activities. According to C D Grant et al. (2006), the students are more prone to learn professional skills if they are included in the curriculum, instead of being taught separately.

At the same time, it must be noted that professional skills cannot be taught overnight to students when they are nearing their graduation. It is an essential life skill which is to be taught and included from the very beginning of their course [(Bhat et al., 2020b). It helps the students to come up with new solutions to problems without focussing barely on the technical aspects. This allows the students to apply the concepts of the problem-solving process which consists of critical factors like understanding the problem statement, putting forth the alternate solutions, assessment and selection of the most suitable solution and finally execution of the solution (Shekar, 2015). This motivated the researchers to analyze the effects of the application of Collaborative Learning techniques and to study how it benefits in increasing the professional skills of first-year students.

\section{Research Methodology}

The present study was conducted using the Action Research approach. In this methodology, instead of merely monitoring the process, the researcher actively involves oneself in the process (Tripp, 2005). This approach guarantees a change in the organization together with understanding the process resulting from participation from the stakeholders (Bhat et al., 2020a). This methodology is best suited if the study is investigative or exploratory. The technique is highly recommended as it treats research and action as indistinguishably intertwined elements of study rather than two separate facets. Moreover, it combines theoretical and practical solutions to evolve practical applications (Binu et al., 2020). Further, Define, Measure, Analyse, Improve, Control (DMAIC) approach of Lean Six Sigma quality assurance phases are used for project deployment and sustainment (Bhat and Jnanesh, 2013)

In this methodology, the teacher being a researcher was directly engaged in developing the case study. Also, the current study was executed on the set of students belonging to a specific semester for the subject named "Elements of Mechanical Engineering" to obtain the answers for the research questions. A collaborative learning technique named STAD was used within the context of OBE. In the study, 55 students took part which consists of 11 teams, each having five members. A heterogeneous team has been set up to ensure that the basic concept of Collaborative Learning is retained. Two Sample Equivalence Test and Paired Equivalence Test were conducted to draw the robust inference.

\section{Case Study}

The present study was conducted in the first year, and $1^{\text {st }}$ semester Electronics \& Communication Engineering students were taken into account. The subject "Elements of Mechanical Engineering". The active learning strategy was chalked out for the topic 'Properties, Composition \& Industrial Application of Engineering Materials (Smart Materials)', and the task was to "A study on Recent Progress of self-powered sensing systems for wearable electronics using Smart Materials". The time duration of 20 days was given to the students to come together as a group, discuss and to conduct an extensive literature survey to obtain key finding regarding the changing scenarios in electronics systems and then finally present the findings in the form of Oral Presentation using PowerPoint Presentation.

\section{A Define}

In the first stage of the process, the project is defined with a rationale to ensure the nitty-gritty of the activity from the perspective of OBE, as shown in Table 1. This also correlates the Programme Outcomes (POs) to the topics under discussion.

\section{B. Measure}

Later, a measurement framework was established in line with the outcome of the activity, ensuring Blooms Levels, POs, Competencies, Performance Indicator and assessment approach, as shown in Table 2.

\section{Analysis}

Further, an extensive brainstorming session was conducted to form the teams, as presented in Table 3 strategically. Eventually, an analysis time frame was developed and 
shared to ensure that the activity can be performed in the stipulated time of 20 days without any obstacles.

\section{Improve}

This stage is concerned with the improvement of professional skills through the evaluation of the group activities assigned to the students. Thus, a comprehensive rubric was developed (Table 5) and shared in advance to ensure students prepared accordingly. This helped to improve professional skills in a structured way. Rubrics were used for the evaluation of the presentation by the groups to avoid uncertainty during the evaluation, thereby ensuring complete transparency in the process (Table 5).

\section{Control}

This phase intended to note the lessons learned in the entire process and to sustain the process by adopting the best practices. Lessons learned and managerial implications of the project deployment were used dynamically adopt the changes during the process.

Table 1: Project Charter

\begin{tabular}{|c|c|}
\hline Criteria & Rational \\
\hline STAD & $\begin{array}{l}\text { - The conduction of this active learning methodology would be beneficial to the team and as well as individual } \\
\text { to practice the fundamentals of the topic chosen (Properties, Composition \& Industrial Application of } \\
\text { Engineering Materials) } \\
\text { - Students can learn through group and individual perceptions on the subject/ topic } \\
\text { - It assists the students to handle up with team-dynamics }\end{array}$ \\
\hline $\begin{array}{l}\text { Topic: Properties, } \\
\text { Composition \& } \\
\text { Industrial Application } \\
\text { of Engineering } \\
\text { Materials } \\
\text { Subtopic: Smart } \\
\text { Materials }\end{array}$ & $\begin{array}{l}\text { - This topic is mapped to PO-9 (Individual and Teamwork), PO-10 (Communicate Effectively) and PO-12 } \\
\text { (Lifelong learning) and in the course plan. } \\
\text { The STAD would assist students to clearly understand the "Properties, Composition \& Industrial Application } \\
\text { of Engineering Materials" not only from the viewpoint of academics but also concerning practicality. It these } \\
\text { modern advancements are being included in the industrial applications. } \\
\text { - Since the topic is more of a hypothetical in nature and a new perspective can be determined from individual } \\
\text { and team levels to improve critical thinking. }\end{array}$ \\
\hline
\end{tabular}

Table 2: OBE Framework for the Project

\begin{tabular}{|c|c|c|c|c|c|}
\hline $\begin{array}{l}\text { Intended } \\
\text { outcome } \\
\text { (At the end of } \\
\text { the activity } \\
\text { students will } \\
\text { be able to) }\end{array}$ & $\begin{array}{l}\text { Blooms Level } \\
\text { (Examination } \\
\text { Reforms, } \\
\text { 2018) }\end{array}$ & $\begin{array}{l}\text { POs Mapped } \\
\text { (General } \\
\text { Manual of } \\
\text { Accreditation, } \\
\text { 2019) }\end{array}$ & $\begin{array}{c}\text { Competency (Examination } \\
\text { Reforms, 2018) }\end{array}$ & $\begin{array}{c}\text { PI (Performance Indicator) } \\
\text { (Examination Reforms, 2018) }\end{array}$ & Assessment \\
\hline \multirow{3}{*}{$\begin{array}{l}\text { Distinguish } \\
\text { between the } \\
\text { various } \\
\text { properties of } \\
\text { Metals, Non- } \\
\text { metals, Plastics, } \\
\text { Ceramics and } \\
\text { Composite } \\
\text { Materials to } \\
\text { find its } \\
\text { applications in } \\
\text { their respective } \\
\text { industries. }\end{array}$} & \multirow[t]{3}{*}{$\begin{array}{l}\text { Level } 4 \\
\text { (Analyse) }\end{array}$} & \multirow[t]{3}{*}{ PO-9, PO-12 } & $\begin{array}{l}\text { Exhibit an ability to delineate } \\
\text { the properties of engineering } \\
\text { materials. }\end{array}$ & $\begin{array}{l}\text { Determine and describe different } \\
\text { roles of 'Engineering Materials'; } \\
\text { as they are going to be the base } \\
\text { for understanding the concepts of } \\
\text { Smart Materials }\end{array}$ & \multirow[t]{3}{*}{$\begin{array}{l}\text { Quiz and } \\
\text { Case } \\
\text { Studies }\end{array}$} \\
\hline & & & $\begin{array}{l}\text { Exhibit an ability to operate in a } \\
\text { team, and define a significant } \\
\text { role for each of the team } \\
\text { member, and take leadership. }\end{array}$ & $\begin{array}{l}\text { Recognize a wide range of } \\
\text { learning styles; realize the value } \\
\text { of team diversity }\end{array}$ & \\
\hline & & & $\begin{array}{l}\text { Exhibit an ability to recognize } \\
\text { lacune in knowledge, and a } \\
\text { strategy is designed to close } \\
\text { these gaps }\end{array}$ & $\begin{array}{l}\text { Describe the rationale for the } \\
\text { requirement for continuing } \\
\text { professional development }\end{array}$ & \\
\hline \multirow{3}{*}{$\begin{array}{l}\text { Elucidate the } \\
\text { industrial } \\
\text { application of a } \\
\text { new class of } \\
\text { materials } \\
\text { through a } \\
\text { presentation by } \\
\text { the team }\end{array}$} & \multirow[t]{3}{*}{$\begin{array}{l}\text { Level 5 } \\
\text { (Evaluate) }\end{array}$} & \multirow[t]{3}{*}{$\begin{array}{l}\text { PO-9, PO-10, } \\
\text { PO-12 }\end{array}$} & $\begin{array}{l}\text { Demonstrate an understanding } \\
\text { new class of engineering } \\
\text { materials and its impact on the } \\
\text { industrial sectors }\end{array}$ & $\begin{array}{l}\text { Understand the relationship } \\
\text { between various properties of } \\
\text { materials, their manufacturing } \\
\text { techniques and correlating it to } \\
\text { the intended application. }\end{array}$ & \multirow{3}{*}{$\begin{array}{l}\text { Oral } \\
\text { Presentation } \\
\text { through } \\
\text { PowerPoint } \\
\text { Presentation } \\
\text { (Team } \\
\text { Assessment) }\end{array}$} \\
\hline & & & $\begin{array}{l}\text { Demonstrate efficiency of the } \\
\text { team, and individual operations, } \\
\text { conflict resolution, } \\
\text { communication, problem- } \\
\text { solving, and leadership skills }\end{array}$ & $\begin{array}{l}\text { Exhibit effective communication, } \\
\text { conflict resolution, problem- } \\
\text { solving, and leadership skills }\end{array}$ & \\
\hline & & & $\begin{array}{l}\text { Exhibit an ability to ascertain } \\
\text { varying trends in 'Smart } \\
\text { Materials' and practice }\end{array}$ & $\begin{array}{l}\text { Identification of the path that led } \\
\text { to the development of smart } \\
\text { materials and hence providing a } \\
\text { broad spectrum to focus the } \\
\text { research area }\end{array}$ & \\
\hline
\end{tabular}


Table 3: Team Establishment Strategy

\begin{tabular}{|c|c|c|c|}
\hline Particulars & Structure & Rationale & Criteria for Selection \\
\hline \multirow{5}{*}{$\begin{array}{l}\text { Total number of } \\
\text { students = 55 } \\
\text { Members in each } \\
\text { team = 5 } \\
\text { Total Teams = } 11 \\
\text { The } \\
\text { heterogeneous } \\
\text { team will be } \\
\text { established to } \\
\text { promote } \\
\text { Collaborative } \\
\text { learning among } \\
\text { the students. } \\
\text { To fulfil the } \\
\text { graduate } \\
\text { attributes defined } \\
\text { by the statutory } \\
\text { authority [24]. }\end{array}$} & $\begin{array}{l}\text { Member 1: Student with obtained more } \\
\text { than } 80 \% \text { in } 12^{\text {th }} \text { or } 2^{\text {nd }} \text { PUC }\end{array}$ & $\begin{array}{l}\text { Students will be able to comprehend the best- } \\
\text { practice embraced by the bright learners and help } \\
\text { in discovering challenging concepts as well as in } \\
\text { critical thinking }\end{array}$ & \multirow{5}{*}{$\begin{array}{l}\text { Determine the top } 11 \\
\text { students by their marks } \\
\text { obtained in 12th or } \\
\text { IInd PUC through } \\
\text { college Student } \\
\text { Information } \\
\text { Management system } \\
\text { (SIMs). } \\
\text { Determine the top } 11 \\
\text { students by their marks } \\
\text { available with the } \\
\text { marks register/ student } \\
\text { portfolio. } \\
\text { Identify } 11 \text { students } \\
\text { who have studied in } \\
\text { English Medium or } \\
\text { who are good in public } \\
\text { speaking or the one } \\
\text { who has good } \\
\text { presentation skills } \\
\text { Rest of the students. }\end{array}$} \\
\hline & $\begin{array}{l}\text { Member } 2 \text { : Student with results varying } \\
\text { between } 60-80 \% \text { in } 12^{\text {th }} \text { or } 2^{\text {nd }} \text { PUC }\end{array}$ & $\begin{array}{l}\text { Students can comprehend the best-practice } \\
\text { implemented by the bright learners }\end{array}$ & \\
\hline & $\begin{array}{l}\text { Member 3: Student who has scored } \\
\text { more than } 20 \text { out of } 50 \text { in the first } \\
\text { internal of the subject under study } \\
\text { "Elements of Mechanical Engineering." }\end{array}$ & $\begin{array}{l}\text { Students those are excellent in core engineering/ } \\
\text { mathematical subjects do not necessarily have to } \\
\text { be good in conceptual/ inter-disciplinary } \\
\text { subjects - each student their very own field of } \\
\text { interest. Thus, one who scored good marks in the } \\
\text { first internal test indicates to some extent } \\
\text { students' interest and knowledge gained in the } \\
\text { area which more team members can tap the for } \\
\text { the success of their team. }\end{array}$ & \\
\hline & $\begin{array}{l}\text { Member 4: Student with effective } \\
\text { communication skills/more excellent } \\
\text { knowledge in harnessing the technology }\end{array}$ & $\begin{array}{l}\text { Some students are particularly interested in public } \\
\text { speaking or have the ability to present a given } \\
\text { topic in front of a large crowd without hesitation. } \\
\text { Thus, one student with this capability must be } \\
\text { added to the team so that there can be effective } \\
\text { communication of the given topic to the target } \\
\text { audience. }\end{array}$ & \\
\hline & $\begin{array}{l}\text { Member 5: Student who will not come } \\
\text { under any of the above categories }\end{array}$ & $\begin{array}{l}\text { Since it is always hard to recognize the students } \\
\text { as per the planned composition and to address } \\
\text { any challenges, this member will be selected } \\
\text { based on the availability }\end{array}$ & \\
\hline
\end{tabular}

Table 4: Activity Analysis Framework

\begin{tabular}{|c|c|}
\hline Description & Rationale \\
\hline $\begin{array}{l}\text { Start Date: } 21 \text { October } 2019 \\
\text { End Date: } 10 \text { November } 2019 \\
\text { Step } 1 \text { ( } 21 \text { October to } 29 \text { October 2019): Brief deliberation on critical aspects of the topic } \\
\text { - Metals, Non-Metals, Ferrous Metals, Aluminium, Copper, Brass, Bronze, Properties of } \\
\text { Materials, Polymers: Thermosetting and Thermoplastics, Ceramics: Glass, Optical Fiber } \\
\text { Glass, Cermets, Composite Materials: Fibre-reinforced composites, metal matrix } \\
\text { composites, Smart Materials: Piezoelectric materials, shape memory alloys, } \\
\text { semiconductors and insulators - Classroom deliberation by the tutor } \\
\text { Step } 2 \text { (29 October to } 07 \text { November } 2019 \text { ): Identification of the relevant materials through } \\
\text { literature survey and preparation of the presentation. - Test } 1 \text { - Quiz (Individual } \\
\text { assessment) }\end{array}$ & $\begin{array}{l}\text { Already started a discussion on the topic in } \\
\text { order to facilitate and provide necessary } \\
\text { information about the topic. Thus, the first step } \\
\text { can be executed within a few days. } \\
\text { Step } 2 \text { is used to assess the learning levels of } \\
\text { the individual students to facilitate them to } \\
\text { step } 3 \text {. } \\
\text { Since students have to collect the relevant } \\
\text { materials through internet research, journal } \\
\text { papers or textbooks and comprehend the } \\
\text { practical perspectives of the topics, a } \\
\text { substantial amount of time has been allotted } \\
\text { (10 days). } \\
\text { Moreover, students need to present their } \\
\text { observations in a PPT, and it demands to } \\
\text { prepare an MS PowerPoint Presentation } \\
\text { professionally and provide information in an } \\
\text { effective way (3 days). }\end{array}$ \\
\hline
\end{tabular}

Table 5: Rubrics used for evaluation of the presentation

\begin{tabular}{|c|c|c|c|c|}
\hline Criteria & $\begin{array}{c}\text { Excellent } \\
\text { (7 Marks) }\end{array}$ & $\begin{array}{c}\text { Good } \\
(5 \text { Marks })\end{array}$ & $\begin{array}{l}\text { Adequate } \\
\text { (3 Marks) }\end{array}$ & $\begin{array}{c}\text { Weak } \\
\text { (1 Marks) }\end{array}$ \\
\hline $\begin{array}{l}\text { Response to } \\
\text { Assignment }\end{array}$ & $\begin{array}{l}\text { In response to the given } \\
\text { assignment, the presentation } \\
\text { addresses the topic at an } \\
\text { appropriate technical level } \\
\text { for the target audience. }\end{array}$ & $\begin{array}{l}\text { The presentation is well } \\
\text { executed in response to the } \\
\text { given topic. However, it has } \\
\text { some minor shortcomings in } \\
\text { putting forth the essential }\end{array}$ & $\begin{array}{l}\text { The presentation permeates } \\
\text { the required response of the } \\
\text { assignment but has } \\
\text { considerable weakness in } \\
\text { explaining the key topics at }\end{array}$ & $\begin{array}{l}\text { The presentation does not } \\
\text { satisfy the brief mentioned } \\
\text { in the assignment and is } \\
\text { badly exhibited. }\end{array}$ \\
\hline
\end{tabular}




\begin{tabular}{|c|c|c|c|c|}
\hline Criteria & $\begin{array}{l}\text { Excellent } \\
\text { (7 Marks) }\end{array}$ & $\begin{array}{c}\text { Good } \\
\text { (5 Marks) }\end{array}$ & $\begin{array}{l}\text { Adequate } \\
\text { (3 Marks) }\end{array}$ & $\begin{array}{c}\text { Weak } \\
\text { (1 Marks) }\end{array}$ \\
\hline & & details. & a technical level & \\
\hline $\begin{array}{l}\text { Analysis and } \\
\text { Discussion }\end{array}$ & $\begin{array}{l}\text { The material presented has } \\
\text { been examined and assessed } \\
\text { through suitable reasoning } \\
\text { points, discussing the } \\
\text { different options, and } \\
\text { delivering examples as } \\
\text { applicable }\end{array}$ & $\begin{array}{l}\text { The material presented has } \\
\text { been examined and assessed } \\
\text { through suitable reasoning } \\
\text { points, discussing the } \\
\text { various choices, and } \\
\text { delivering examples are } \\
\text { given in some cases only }\end{array}$ & $\begin{array}{l}\text { The material presented has } \\
\text { been examined and assessed } \\
\text { but has failed to mention } \\
\text { any of the supporting facts } \\
\text { to connect the topic }\end{array}$ & $\begin{array}{l}\text { The profundity of analysis } \\
\text { and assessment of the } \\
\text { presented material is not } \\
\text { adequate, and discussion is } \\
\text { based on the pointless } \\
\text { debate without evidence }\end{array}$ \\
\hline Organization & $\begin{array}{l}\text { The organization of the } \\
\text { contents in the presentation } \\
\text { is well structured with all } \\
\text { the technical details } \\
\text { mentioned with proper } \\
\text { clarity }\end{array}$ & $\begin{array}{l}\text { Though the presentation is } \\
\text { well structured, it has } \\
\text { minimal setbacks in the } \\
\text { overall organization. }\end{array}$ & $\begin{array}{l}\text { The structure of the } \\
\text { presentation is satisfactory } \\
\text { but the organization of the } \\
\text { contents ideal to support the } \\
\text { delivery of content }\end{array}$ & $\begin{array}{l}\text { The presentation is } \\
\text { ineffectively organized; the } \\
\text { structural flaws weaken its } \\
\text { effectiveness and clarity }\end{array}$ \\
\hline $\begin{array}{l}\text { Speaking } \\
\text { Skills }\end{array}$ & $\begin{array}{l}\text { Speaker is adequately } \\
\text { prepared, sets out efficient } \\
\text { eye contact with the viewer, } \\
\text { communicates distinctly and } \\
\text { audibly, stays on topic and } \\
\text { completes the presentation } \\
\text { on time }\end{array}$ & $\begin{array}{l}\text { Speaker is prepared and } \\
\text { acquainted with the content } \\
\text { of the visual aids, but may } \\
\text { sometimes deviate from the } \\
\text { topic and have other } \\
\text { shortcomings in speaking } \\
\text { style }\end{array}$ & $\begin{array}{l}\text { Speaker is moderately } \\
\text { prepared but has a tendency } \\
\text { to look at visual aids for } \\
\text { prompting and is not being } \\
\text { able to communicate all the } \\
\text { planned content }\end{array}$ & $\begin{array}{l}\text { Speaker is not ready and has } \\
\text { to read it from the visual } \\
\text { aids or cue cards, does not } \\
\text { use the speech or body } \\
\text { language efficiently to } \\
\text { connect the audience to the } \\
\text { topic }\end{array}$ \\
\hline Conclusions & $\begin{array}{l}\text { Keypoints are re-stated } \\
\text { towards the end of the talk } \\
\text { in such a manner that the } \\
\text { audience understands the } \\
\text { objective of the technical } \\
\text { work }\end{array}$ & $\begin{array}{l}\text { The presentation contains a } \\
\text { conclusion, but numerous of } \\
\text { the critical points are not } \\
\text { emphasized effectively }\end{array}$ & $\begin{array}{l}\text { The presentation contains a } \\
\text { short conclusion although it } \\
\text { is not significant to the } \\
\text { content }\end{array}$ & $\begin{array}{l}\text { The presentation seems to } \\
\text { have an abrupt end without } \\
\text { having any summary for the } \\
\text { viewers. }\end{array}$ \\
\hline
\end{tabular}

\section{Results and Discussion}

Eventually, the assessment metrics were compared to statistically to ascertain the improvement and to determine the answers to the RQs. Initially, the attainment of POs was compared to determine the effectiveness of Collaborative learning to enhance the professional skills among the students. For this purpose, Two-Sample Equivalence test was conducted taking into account of the attainment of each POs individually of the present section of students who have undergone collaborative learning approach and those students of the previous batch who have been taught by the same tutor without collaborative learning methodology to assess the POs. Further, the attainment target was fixed at level 2 and rage of \pm 0.5 was used to accommodate the variations in the learning levels. The results are shown in Table 6, indicates the two approaches (Collaborative Learning and Lecturing) are not equivalence in all the three PO attainment. Further, from Equivalence Plot (Figure 1) and Box Plot (Figure 2), it can be determined that the outcome attainment with the new pedagogical approach is substantially better compared to the previous approach. Besides, Paired Equivalence Test was conducted to comprehend the improvement in the learning levels of slow learners (categorized as those who have got less than 20 marks out of 50 in the first internal test for the same subject). The lower limit and upper limit of progressive learners were fixed as 20 to 40 marks whereas bright learns as above 40 marks. From the analysis (Figure 3), it was observed that slow learners have improved their learning levels and elevated to themselves to the progressive learner category.

During the study, it was determined that in order to attain the soft POs (PO6-12) active learning strategies are essential as these POs are aligned towards Knowledge and Attitude categories. Also, it is evident from the study that structured POs assessment rubrics assist in scientifically quantifying the attainment levels. Further, it was ascertained that a heterogeneous group formation strategy helps the slow learners to imbibe the concept better way and inculcate critical thinking. Also, new methodology ensured optimal utilization of available time and dissemination of knowledge by effectively utilizing the beyond college hours.

Table 6: Two-Sample Equivalence Test Results

Null hypothesis: Difference $\leq-0.5$ or Difference $\geq 0.5$

Alternative hypothesis: $-0.5<$ Difference $<0.5$

$\alpha$ level: 0.05 
Journal of Engineering Education Transformations, Volume 34, January 2021, Special issue, eISSN 2394-1707

\begin{tabular}{|c|c|c|c|c|c|c|c|c|c|}
\hline & \multicolumn{3}{|c|}{ PO-9 } & \multicolumn{3}{|c|}{ PO-10 } & \multicolumn{3}{|c|}{ PO-12 } \\
\hline Null Hypothesis & DF & T-Value & P-Value & DF & T-Value & P-Value & DF & T-Value & P-Value \\
\hline Difference $\leq-0.5$ & 92 & 11.855 & 0.000 & 86 & 18.447 & 0.000 & 67 & 23.614 & 0.000 \\
\hline Difference $\geq 0.5$ & 92 & 1.2536 & 0.893 & 86 & 6.1032 & 1.000 & 67 & 7.2107 & 1.000 \\
\hline Interpretation & \multicolumn{3}{|c|}{$\begin{array}{l}\text { The greater of the two P-Values is } \\
0.893 \text {. Cannot claim equivalence. }\end{array}$} & \multicolumn{3}{|c|}{$\begin{array}{l}\text { The greater of the two P-Values is } \\
\text { 1.000. Cannot claim equivalence. }\end{array}$} & \multicolumn{3}{|c|}{$\begin{array}{l}\text { The greater of the two P-Values is } \\
1.000 \text {. Cannot claim equivalence. }\end{array}$} \\
\hline
\end{tabular}

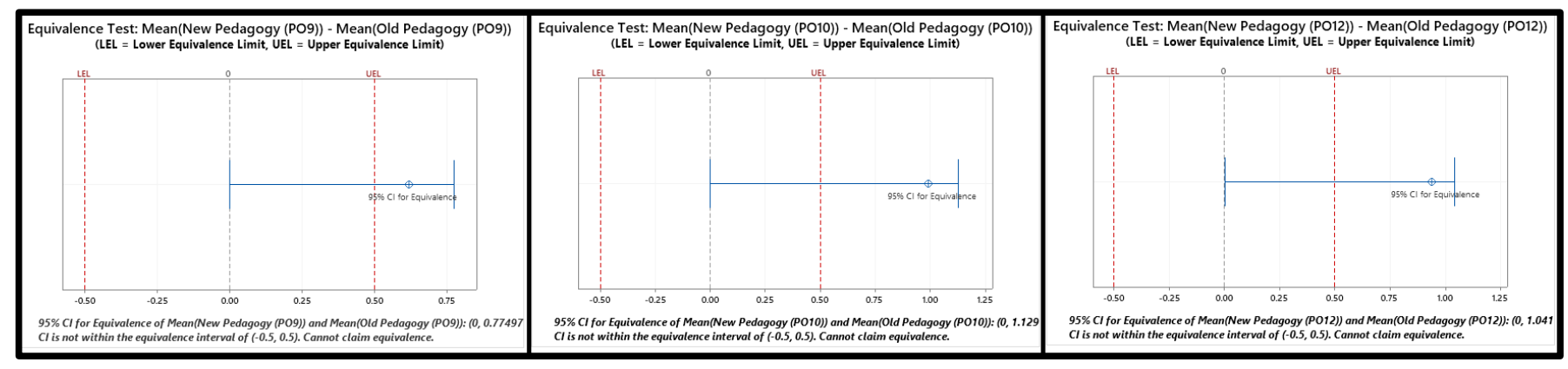

Fig. 1 Equivalence Plot for PO Attainment

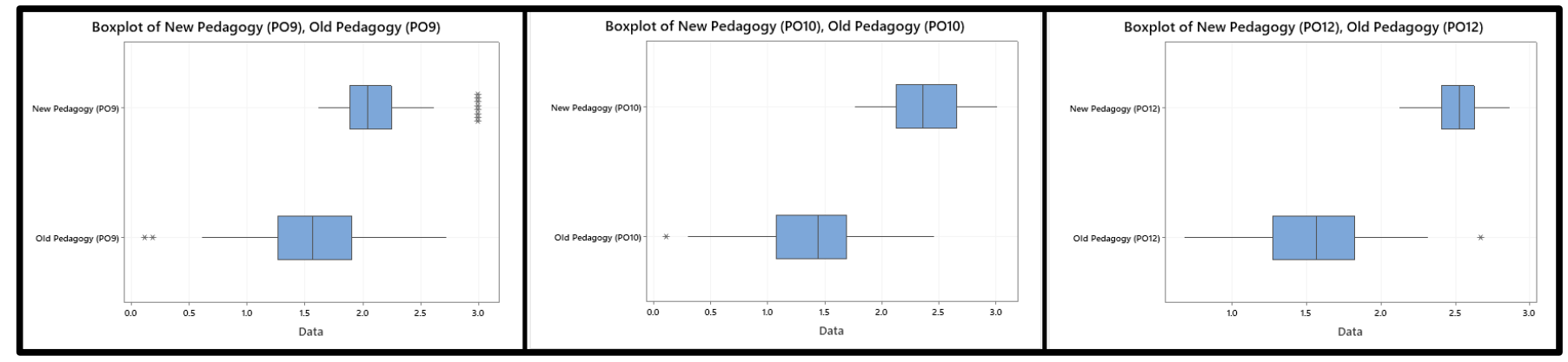

Fig 2. Box Plot for PO Attainment

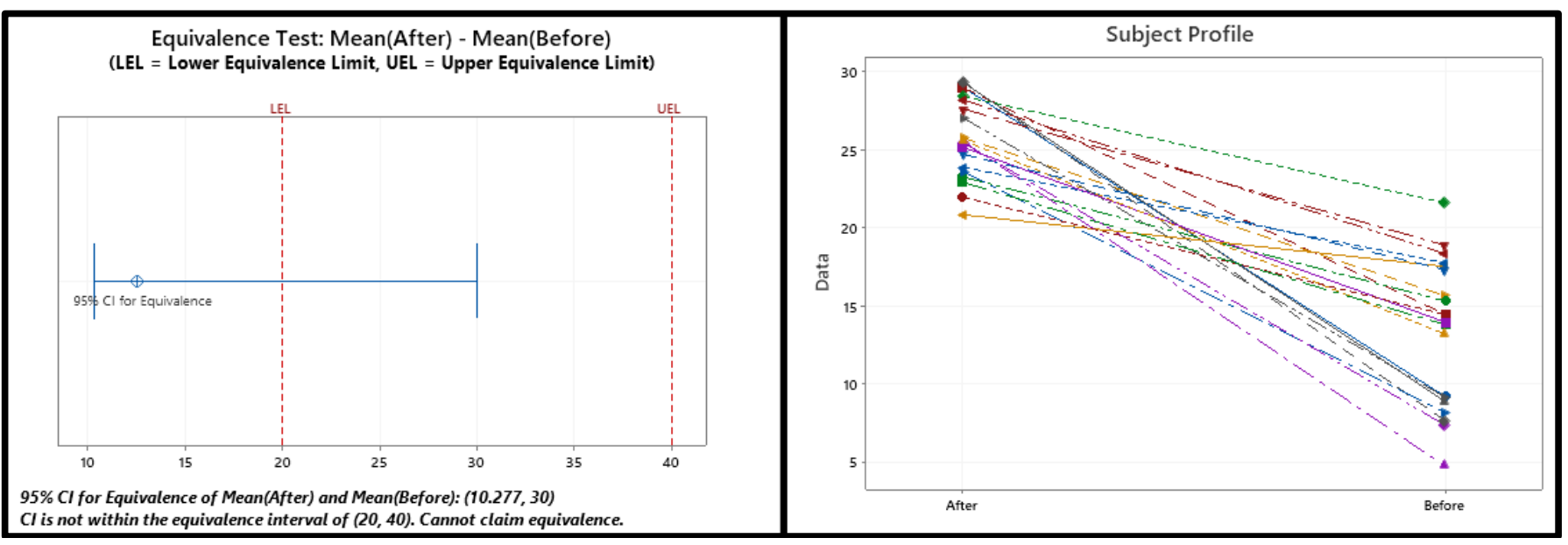

Fig 3. Equivalence Plot and Subject Profile Plot for Slow Learners

\section{Conclusions}

After proper examination and analysis of data obtained through initial assessment and presentation, it can be concluded that a clear distinction is noticed in the ability of the student to analyze and evaluate the concepts presented to them through collaborative learning approach. The students were able to inculcate the habit of critical thinking among them by working together rather than regular learning. Further, the following answers were determined for the RQs.

RQ1: The STAD can be effectively applied to the OBE process with structure approach such as DMAIC.

RQ2: Heterogeneous Group Formation, Specific and Scientific Rubrics for the Assessment of POs, establishing 
PIs and competencies for POs in-line with Blooms Levels, and Developing rationale for each action are the successful strategies for the deployment of collaborative learning in the Engineering Education.

RQ3: The study showed that a structured approach in the deployment of Collaborative Learning ensures better attainment of POs. Also, from the research, it is evident that it assists the system to elevate the students from slow learner category to the progressive learner category.

During the project, the researchers have confronted with the challenges addressing the prevailing issues such as comprehensive understanding to pedagogies of engagement, holistic knowledge of engineering education, and learning styles of the student. These challenges have overcome with the involvement of pioneers in the field and the mentorship of senior professors - eventually, the project assisted in determining a comprehensive strategy to reinforce the professional skills among the students.

\section{Acknowledgement}

The authors would like to express a deep sense of gratitude to the management of St Joseph Engineering College for creating an eco-system for executing the current research in engineering education.

\section{References}

Bhat S. and Jnanesh N.A. (2013) Transforming Higher Education with Lean Six Sigma, HEF Indian Journal of Higher Education, 3(2), 81-85.

Bhat S., D'Souza R., Bhat S., Raju R. and Kumara P. B. (2020a) Effective Deployment of Outcome Based Education: Strategies based on Motivational Models, Journal of Engineering Education Transformation, 33, 164-169.

Bhat S., D'Souza R., Bhat S., Raju R., and Binu K. G. (2020b) Collaborative Learning for Outcome Based Engineering Education: A Lean Thinking Approach, Procedia Computer Science, 172, 927936.

Bhat, S., Raju R., Bhat S. and D'Souza R. (2020c), Redefining Quality in Engineering Education through the Flipped Classroom Model, Procedia Computer Science, 172, 906-914.

Binu K. G., Vijay V. S., Anusha M. M., Anoop C. V, Bhat S. and D'Souza R. (2020) Influence of Epistemic Curiosity on the Study Approaches of First-Year Engineering Students, Procedia Computer Science, 172, 443-451.

Buke M. V., Tondare S. M. and Panchal S. D. (2015) Engineering Education in India: Ethics and Stakeholders Perspective, American Journal of Educational Research, 3(2), 137-141.

Examination Reforms (2018) AICTE. Available at: https://www.aicteindia.org/sites/default/files/ExaminationReforms.p df (Accessed on 20 November 2020).

Froyd J. E., Wankat P. C. and Smith K. A. (2012) Five Major Shifts in 100 Years of Engineering Education, Proceedings of the IEEE.
General Manual of Accreditation (2019). NBA. Available at http://www.nbaind.org/files/general-manual-ofaccreditation.pdf (Accessed on 20 November 2020).

Göl Ö., and Nafalski A. (2007) Collaborative Learning in Engineering Education, Global Journal of Engineering Education, 11(2), 173-180.

Grant C. D. and Dickson B. R. (2006) Personal Skills in Chemical Engineering Graduates: The Development of Skills Within Degree Programmes to Meet the Needs of Employers, Education for Chemical Engineers, 1(1), 2329.

Jadhava M. R., Kakadea A. B., Jagtapa S. R. and Patila M. S. (2019) Impact assessment of outcome-based approach in engineering education in India, Proceedings of $9^{\text {th }}$ World Engineering Education Forum, WEEF-2019.

Kagan S. (1994) Cooperative Learning, Kagan Publishing: San Clemente, CA.

Koehn E. (2001) Assessment of communications and collaborative learning in civil engineering education, Journal of Professional Issues in Engineering Education and Practice, 127(4), 160-170.

Kojmane J. and Aboutajeddine A. (2016) Strengthening engineering design skills of first-year university students under resources constraints, International Journal of Mechanical Engineering Education, 4(2), 148-164.

Kulturel-Konak S., Konak A. O. K. G. and Esparragoza I., (2015) Professional Skills Assessment: Is a Model of Domain Learning Framework Appropriate, International Journal of Quality Assurance in Engineering and Technology Education, 4(1), 3360.

Llorens A., Berbegal J. M. and Llinàs X. A. (2016) Aligning professional skills and active learning methods: an application for information and communications technology engineering, European Journal of Engineering Education, 42(4), 382-395.

Micheal M. V. W. (2012) The Effects of the STADCooperative Learning Method on Student Achievement, Attitude and Motivation in Economics Education, Journal of Social Sciences, 33(2), 261-270.

Mohanty A., and Dash D. (2016) Engineering Education in India: Preparation of Professional Engineering Educators, Journal of Human Resource and Sustainability Studies, 4, 92-101.

Shekar A. (2015) Global perspectives: First-year engineering students' views on social engineering projects, International Journal of Mechanical Engineering Education, 43(2) 102-109.

Stover S. and Holland C. (2018) Student Resistance to Collaborative Learning, International Journal for the Scholarship of Teaching and Learning, 12(2), $1-11$.

Tripp D. (2005), Action research: a methodological introduction, Educação e Pesquisa 31(3), 444-467. 